\title{
Hexacyanoferrate-Adapted Biofilm Enables the Development of a Microbial Fuel Cell Biosensor to Detect Trace Levels of Assimilable Organic Carbon (AOC) in Oxygenated Seawater ${ }^{\dagger}$
}

Liang Cheng *, Soon Bee Quek, Ralf Cord-Ruwisch.

*Corresponding author: School of Engineering and Information Technology, Murdoch University, 90, South Street, Perth, WA 6150, Australia. Tel.: +6189360 2804.

Email address: L.Cheng@murdoch.edu.au (L. Cheng), s.quek@murdoch.edu.au (S.B. Quek), R.CordRuwisch@murdoch.edu.au (R. Cord-Ruwisch).

${ }^{\dagger}$ This article has been accepted for publication and undergone full peer review but has not been through the copyediting, typesetting, pagination and proofreading process, which may lead to differences between this version and the Version of Record. Please cite this article as doi: [10.1002/bit.25315]

(c) 2014 Wiley Periodicals, Inc.

Received February 11, 2014; Revision Received June 06, 2014; Accepted June 10, 2014 


\begin{abstract}
A marine microbial fuel cell (MFC) type biosensor was developed for the detection of assimilable organic carbon (AOC) in ocean water for the purpose of online water quality monitoring for seawater desalination plants prone to biofouling of RO membranes. The anodophilic biofilm that developed on the graphite tissue anode could detect acetate as the model AOC to concentrations as low as $5 \mu \mathrm{M}(320 \mu \mathrm{g} / \mathrm{L}$ of AOC), which is sufficiently sensitive as an online biofouling risk sensor. Although the sensor was operated at a higher $(+200 \pm 10 \mathrm{mV})$ than the usual $(-300 \mathrm{mV})$ anodic potential, the presence of oxygen completely suppressed the electrical signal. In order to overcome this outcompeting effect of oxygen over the anode as electron acceptor by the bacteria, hexacyanoferrate (HCF(III)) was found to enable the development of an adapted biofilm that transferred electrons to $\mathrm{HCF}(\mathrm{III})$ rather than oxygen. As the resultant of the reduced $\mathrm{HCF}$ (II) could readily transfer electrons to the anode while being re-oxidised to HCF(III), the marine MFC biosensor developed could be demonstrated to work in the presence of oxygen unlike traditional MFC. The possibility of operating the marine MFC in batch or continuous (in-line) mode has been explored by using coulombic or potentiometric interpretation of the signal.
\end{abstract}

Key Words: Biosensor; Hexacyanoferrate; Microbial Fuel Cell; Seawater; Assimilable Organic Carbon; 


\section{Introduction}

Seawater desalination by reverse osmosis (RO) has become a common technology as a result of the lack of consistent freshwater supply in many cities (Baker, 2004). One of the main technical problems of seawater RO plants is membrane fouling leading to shortened membrane lifetime and causing increased power requirements for the desalination plant.

It has been estimated that the largest contribution to membrane fouling is attributed to the activity of marine bacteria (Matin et al., 2011) that feed on organic contaminants in the feedwater and establish bacterial biofilms on the membrane surface. Next to the use of physical and chemical pre-treatments to control biofilm development, it is also useful to be able to monitor the potential of biofilm build-up by sensing the concentration of assimilable organic carbon (AOC) in the feed water. Knowledge about the levels of such degradable organic contaminants allows the plant operator to develop an efficient anti-biofouling strategies, or if applicable to draw feedwater from somewhere else. Such information on AOC should ideally be acquired on-line, in-situ, non-destructively, in real time, representatively, accurately, reproducibly, and automatically (Van der Kooij, et al., 2010).

Techniques utilized for monitoring biofouling include detection of biofilm formation (e.g. biofilm formation rate (BFR) (Van der Kooij, 1992)), system performance analysis (e.g. pressure drop, oxygen uptake, permeate flux etc. (Saad, 2004; Brouwer et al., 2006), and the analysis of the feed water. Many different physical, chemical, and biological parameters have been utilized to identify the intake feed water quality. Total direct cell count (TDC) enables an estimate of cells that contribute to biofilm formation 
or mere physical deposition of cells (Holm-Hansen et al., 1966). The ATP (intracellular adenosine-tri-phosphate) content is a more involved method that reflects on the overall level of active biomass (Hobbie et al., 1977). As most RO plants use effective prefiltration to remove cellular material, the above measurements are not relevant to most of the industry. Instead the direct measurement of assimilable organic carbon (AOC), substances that could promote microbial growth and leading to biofouling has been the focus of recent research (Nguyen et al., 2012).

For the detection of biodegradable organic substances in wastewater the method of Biochemical Oxygen Demand (BOD) is being widely used (Bourgeois et al., 2001; Eaton and Franson, 2005). Traditional BOD tests require a 5-day off-line laboratory incubation $\left(\mathrm{BOD}_{5}\right)$ making it not suitable for a fast and online monitoring system. Recently, other types of BOD biosensors were based on measuring the decrease in dissolved oxygen (DO) by a suspended or immobilised microbial biomass when exposed to the test solution (Chee et al., 1999; Liu et al. 2000; Riedel et al., 1998; Sangeetha et al., 1996). These methods require a sensitive dissolved oxygen (DO) electrode and are limited by the low solubility of oxygen in water $\left(8.84 \mathrm{mg} \mathrm{O}_{2} \mathrm{~L}^{-1}\right.$ at 1 atm, $\left.20{ }^{\circ} \mathrm{C}\right)$.

Alternatively, some research works have been conducted using mediators (artificial electron acceptors) instead of oxygen as electron acceptor (Jordan et al., 2010; Jordan et al., 2013; Nakamura et al., 2007; Pasco et al., 2000). The test bacteria would reduce the mediator, which can be detected photospectrometically or electrochemically. For example, Nakamura et al. (2007) have developed a highly sustainable BOD biosensor using eukaryote, Saccharomyces cerevisiae, coupled with two mediators, ferricyanide 
and menodione. However, those methods are not designed for on-line measurement, as regular sample harvesting is required.

Microbial fuel cells (MFC) are devices in which microbial biofilms on a conductive electrode (anode) generate an electron flow from the oxidation of AOC (Logan et al., 2006; Pant et al., 2010). MFCs have been proposed as online biosensor for continuous determination of BOD (Chang et al., 2005; Kumlanghan et al., 2007; Pasco et al., 2004). The reactions (with acetate as the organic BOD) occurring in the anode and cathode compartments can be expressed as Equations (1) and (2):

Anode (acetate):

$$
\mathrm{CH}_{3} \mathrm{COO}^{-}+4 \mathrm{H}_{2} \mathrm{O} \rightarrow 2 \mathrm{HCO}_{3}^{-}+9 \mathrm{H}^{+}+8 \mathrm{e}^{-}
$$

Cathode (ferricyanide): $\quad \mathrm{Fe}(\mathrm{CN})_{6}{ }^{3-}+\mathrm{e}^{-} \rightarrow \mathrm{Fe}(\mathrm{CN})_{6}{ }^{4-}$

By measuring the voltage across the external resistor, the current flowing in the system can be calculated using Ohm's law. Ideally, the current or number of electrons (cumulative charges) transferred in the MFC is correlated to the amount of BOD oxidised and can be used to calculate the initial BOD concentration. Such a correlation between cumulative charges and BOD concentration can only be obtained by batchfeeding the organics to the anodophilic biofilm. Current represents the oxidation rate of organic substrates by the bacteria attached to the anode, which under substrate limitation condition, according to the well-known phenomenon of Monod growth kinetics (Modin and Wilén, 2012), would be expected to be correlated to the substrate (BOD) concentration. Hence, to obtain direct BOD estimations from current readings, very low BOD levels are needed, which is exactly the case for the low AOC levels in seawater. 
In previous extensive studies, MFC biosensors for BOD detection were developed for detecting organic substrates in wastewater (Di Lorenzo et al., 2009), ground water (Ling et al., 2003) and anaerobic digestion liquid (Liu et al., 2011). There are limited numbers of published works for utilising MFC biosensor for the detection of trace amount of organic matters in seawater. Desired characteristics of a MFC biosensor for the prediction of biofouling potential on the RO membrane are:

- sensitive to trace amounts of organic matter in the ocean $(\sim 100 \mu \mathrm{mol} / \mathrm{L}$ dissolved organic carbon (Taki and Suzuki, 2001), or less than $5 \mathrm{mg} / \mathrm{L}$ BOD (Chen et al., 2008)),

- a good representation of the biofouling biofilm by the microbial population on the anode of the MFC (i.e. marine bacteria biofilm rather than defined cultures of bacteria or yeast cells), and

- tolerant to saturated concentrations of dissolved oxygen.

In particular, the last point is not readily implementable because it is well known that electron flow in conventional MFCs is suppressed by dissolved oxygen (Bond et al., 2003; Liu et al., 2005; Ringeisen et al., 2007, Shukla et al., 2004).

The current study aims to develop a MFC based AOC sensor that addresses the above three points by using a marine biofilm enriched on the MFC anode and optimising it for the detection of extremely low AOC in the presence of dissolved oxygen levels typically encountered in ocean water. Acetate was used as the model substrate as it is universally present and also it is the key biological breakdown product from more complex organic substances. 


\section{Materials and Methods}

\section{MFC sensor design and inoculation}

The MFC biosensor was comprised of cathodic and anodic compartments with same dimension $(9 \mathrm{~cm} \times 6 \mathrm{~cm} \times 1 \mathrm{~cm})$, separated by a cation selective membrane (cross section area: $54 \mathrm{~cm}^{2}$ ) (CMI-6000, Membrane International INC). The cathode compartment was filled with $50 \mathrm{~g}$ of conductive graphite granules (EI Carb 1000, Graphites Sales, Inc., Chagrin Falls, OH, USA), of about 2-4 $\mathrm{mm}$ in diameter. The anode was made of $54 \mathrm{~cm}^{2}$ knitted carbon cloth (C-TEX 100, MAST Carbon Advanced Products Ltd), of about $70 \mathrm{~g} / \mathrm{m}^{2}$ in density and $1100 \mathrm{~m}^{2} / \mathrm{g}$ in surface area (data provided by the manufacturer). As a collector for external wire connections, the graphite granules and carbon clothes were connected to graphite rods (5 $\mathrm{mm}$ diameter), which were connected via an adjustable resistor. The potentials of the two electrodes were measured against a saturated $\mathrm{Ag} / \mathrm{AgCl}$ reference electrode (BASi, MF-2079), which was placed inside the anodic compartment.

The bacterial inoculum $(100 \mathrm{~mL})$ was extracted from ocean sediment $\left(\mathrm{OD}_{600}\right.$ value of about 0.2), collected from Coogee Beach, Coogee, South Fremantle, Western Australia.

\section{MFC biosensor start-up}

The MFC biosensor was established under a batch mode. The anodic compartment was continuously circulated with $100 \mathrm{~mL}$ of the bacterial inoculum at a flow rate of 100 $\mathrm{mL} / \mathrm{min}$. The growth medium consisted of $0.5 \mathrm{~g} / \mathrm{L}$ marine broth $\left(\mathrm{BD}\right.$ Difco $\left.{ }^{\mathrm{TM}}\right)$ and 5 mM sodium acetate in real sea water and was replaced periodically.

The cathodic chamber was continuously circulated with $250 \mathrm{~mL}$ of $100 \mathrm{mM}$ potassium hexacyanoferrate (HCF(III)) (Sigma-Aldrich, Inc., purity ca. 99\%). The catholyte was 
renewed periodically to maintain a stable cathodic potential of about $220 \pm 5 \mathrm{mV}$ (vs $\mathrm{Ag} / \mathrm{AgCl})$. The voltage difference between the anode and cathode electrodes was measured across a fixed resistance with $22 \Omega$, if not otherwise specified. During the start-up period, the anodic potential was about $+200 \mathrm{mV}(\mathrm{vs} \mathrm{Ag} / \mathrm{AgCl})$.

To adapt the MFC biomass to HCF(III) the established MFC was operated for two weeks in the presence of $200 \mu \mathrm{M}$ acetate (added daily) and $200 \mu \mathrm{M} \mathrm{HCF}(\mathrm{III})$. In order to prevent the accumulation of bio-products in the biosensor, the anolyte was replaced regularly with fresh seawater (Coogee Beach, South Fremantle, Western Australia).

\section{MFC biosensor operation and evaluation}

The MFC biosensor was continuously operated in the presence $\mathrm{HCF}(\mathrm{III})$ at room temperature $\left(20 \pm 2{ }^{\circ} \mathrm{C}\right)$ for four months. The anodic potential, cell potential (potential difference between anode and cathode), dissolved oxygen (DO) and $\mathrm{pH}$ of the anolyte were monitored continuously using LabVIEW ${ }^{\mathrm{TM}} 7.1$ software interface with a National Instrument $^{\mathrm{TM}}$ data acquisition card (DAQ) as described previously (Cheng et al., 2008). The $\mathrm{pH}$ of the anolyte was strictly controlled at $7.5 \pm 0.2$ by periodically dosing $\mathrm{NaOH}$ (1 M).

Organic substrates detection: Specified concentrations of various types of organic substrates, including sodium acetate $(5$ to $80 \mu \mathrm{M})$, glucose $(20 \mu \mathrm{M})$, sucrose $(20 \mu \mathrm{M})$, L-glutamic $(20 \mu \mathrm{M})$, L-Methionine $(20 \mu \mathrm{M})$, L-Arginine $(20 \mu \mathrm{M})$, L-Aspartic acid $(20$ $\mu \mathrm{M})$, L-Ascorbic $(20 \mu \mathrm{M})$ and $\beta$-Alanine $(20 \mu \mathrm{M})$, were added into the anodic circulation loop to test for responses of the MFC biosensor by measuring the change in current or cell voltage. The external resistance was adjusted from 22 to $5 \mathrm{ohm}$. 
Effect of the mediator (HCF(III)) on oxygen suppression: In order to test the effect of $\mathrm{HCF}(\mathrm{III})$ on the signals production of MFC in the presence of saturating concentrations of dissolved oxygen, $\mathrm{HCF}(\mathrm{III})$ was added to specified concentrations (0.2 to $0.8 \mathrm{mM}$ ) into the anodic compartment. The response of the sensor to the acetate addition was evaluated by adding acetate into the aerated anodic compartment. The aeration was conducted via an air pump with an airflow rate of about $1 \mathrm{~L} / \mathrm{min}$ and the dissolved oxygen monitored online by using a polarographic oxygen electrode (Mettler-Toledo, Ltd) with detection limit of $\pm 0.1 \mathrm{mg} / \mathrm{L}$.

\section{Continuous flow (in-line) mode of operation}

Apart from the measurements mentioned above, the established MFC was also operated in continuous flow mode to detect the AOC (i.e. acetate) pollutant. The continuous mode operation was done by passing a series of prepared seawater feed solutions ( 0.5 to $2 \mathrm{~L})$, containing different concentrations of acetate $(0$ to $80 \mu \mathrm{M})$, through the anodic compartment once (without recirculation). The flow rate was about $25 \mathrm{~mL} / \mathrm{min}$ (hydraulic retention time $(\mathrm{HRT})=2 \mathrm{~min})$. As the continuous flow system contained saturated DO $(>6.5 \mathrm{mg} / \mathrm{L}), 0.4 \mathrm{mM} \mathrm{HCF}(\mathrm{III})$ was added in the feed solutions to overcome the toxicity of the dissolved oxygen.

\section{Analytic methods}

The current (I, mA) was calculated according to the Ohm's law, I = V / R, where V is the cell voltage $(\mathrm{mV})$ and $\mathrm{R}$ is the external resistance $(\Omega)$. The signals of cell voltage or current peak were adjusted by subtracting the background/steady state values in the absence of acetate. The cumulative charges (i.e. total coulombs) were calculated by integrating the electrons transferred through the external resistance as current throughout the detection period (Cheng et al., 2008). The coulombic efficiency (CE) 
(Eq. 3) was calculated from the total electrons extracted from the substance for conversion into electricity versus that in the starting organic materials (Logan et al., 2006).

$C E \%=\frac{c_{s}}{\epsilon_{T}} \times 100=\frac{\int_{S}^{*} E t}{\sigma_{T}} \times 100$

Where $c_{p}$ is the total Coulombs calculated by integrating the current overtime,

calculated as $C_{\mathrm{p}}=\int_{0}^{t} E d t . C_{T}$ is the theoretical accumulated charge (Coulombs) that can be produced from the total substrate input.

The HCF(III) concentration was determined by measuring the optical density of $\mathrm{HCF}(\mathrm{III})$ solution at $420 \mathrm{~nm}$ (Appleby and Morton, 1959). A series of $\mathrm{HCF}(\mathrm{III})$ standard solutions were prepared by adding specific concentration of $\mathrm{HCF}$ (III) into micro-filtered $(0.45 \mu \mathrm{m})$ seawater. A standard curve indicated that in a range between 0.01 and $1 \mathrm{mM}$ concentration, a linear relationship $\left(\mathrm{R}^{2}=0.9996\right)$ between the $\mathrm{HCF}(\mathrm{III})$ concentration and the optical density (OD) was obtained (Eq. 4). The presence of reduced $\mathrm{HCF}$ (II) up to $10 \mathrm{mM}$ did not interfere significantly with the readings at 420 nm the $\mathrm{HCF}(\mathrm{III})$ concentration determination.

$$
\mathrm{C}_{\mathrm{HCF}(\mathrm{III})}(\mathrm{mM})=1.1267 \times \mathrm{OD}_{420}-0.0116\left(\mathrm{R}^{2}=0.9996\right)
$$

\section{Results and Discussion}

Performance of mediator free and mediator $\left(\mathrm{K}_{3} \mathrm{Fe}(\mathrm{CN})_{6}\right)$ adapted marine MFC biosensor

A microbial fuel cell was set up and operated for two months with an anodic potential of about $+200 \mathrm{mV}$ (section 2.2), which is significantly higher than the potential 
normally used for MFC for the purpose of electricity production. The use of +200 instead of $-300 \mathrm{mV}(\mathrm{vs} \mathrm{Ag} / \mathrm{AgCl}$ ) of anode was expected to enable better tolerance to dissolved oxygen. After setup and reproducible current production was obtained, the MFC described (section 2.3) was tested for its ability to detect step changes of acetate concentration in the absence of oxygen (Fig. 1a). Acetate concentrations down to levels of about $10 \mu \mathrm{M}$ were reproducibly detected. To be useful for real seawater applications, the MFC biosensor should also operate in the presence of dissolved oxygen. However, when the anodic compartment was aerated, the presence of dissolved oxygen completely suppressed signal production. This observation of the MFC failed to produce current in the presence of oxygen is in line with other previous findings (Bond et al., 2003; Liu et al., 2005; Ringeisen et al., 2007, Shukla et al., 2004).

The presence of oxygen immediately stopped the current flow and initiated a bacterial oxygen consumption, which showed that oxygen was the preferred electron acceptor of the system. The current biofilm has been developed at substantially higher anodic potential $(+200 \mathrm{mV}(\mathrm{vs} \mathrm{Ag} / \mathrm{AgCl}))$ than what is normally used for MFC (-300 to -400 $\mathrm{mV}$ (vs $\mathrm{Ag} / \mathrm{AgCl})$ ). The electrolytic oxygen reduction by the electrode at this high anodic potential is negligible. Therefore, any oxygen consumption in the anode compartment can be explained by the respiration of the biomass.

Studies with suspended aerobic bacteria have observed that aerobic bacteria prefer potassium $\mathrm{HCF}(\mathrm{III})$ as electron acceptor over oxygen when both are present. High concentrations of $\mathrm{HCF}$ (III) $(>40 \mathrm{mM})$ enabled aerobic bacteria to reduce $\mathrm{HCF}$ as the preferred electron acceptor over oxygen, which is soluble to only about $0.25 \mathrm{mM}$ (Bonetto et al., 2010; Liu et al., 2010). Similarly Yoshida et al. (2000) demonstrated 
that equally high concentrations $\mathrm{HCF}$ (III) functioned as mediator for electron shuttling between aerobic Pseudomonas suspensions and an electrode, even in the presence of low concentrations of dissolved oxygen.

In order to compete with oxygen as the preferred electron acceptor in the above experiment, $0.2 \mathrm{mM}$ of $\mathrm{HCF}(\mathrm{III})$ was added into the anodic compartment. However, oxygen still prevented effective electron transfer of the anodophilic biofilm to the anode (data not shown).

After about two-weeks of operation in the presence of $0.2 \mathrm{mM} \mathrm{HCF(III),} \mathrm{MFC} \mathrm{seemed}$ to have adapted to the preferential use of $\mathrm{HCF}(\mathrm{III})$ as electron acceptor: the MFC biosensor started to produce clear and reproducible signals (e.g. $2 \mathrm{mV}$ cell potentials with $20 \mu \mathrm{M}$ acetate addition) within one hour, in the presence of oxygen (Fig. 1b). This suggested that it is possible to determine low levels of AOC in oxygen-saturated seawater without the need for an additional process of oxygen removal.

In the presence of $\mathrm{HCF}(\mathrm{III})$ as mediator, a decrease in oxygen concentration was still observed, suggesting the usage of a proportion of the AOC for aerobic respiration. Yoshida et al. (2000) also found that even in the presence of $40 \mathrm{mM} \mathrm{HCF}(\mathrm{III})$, oxygen consumption by Pseudomonas fluorescens continued. This might be the reason why a lower current peak (about 50\%) was obtained in the presence of oxygen (Fig. 1b). Nevertheless elimination of oxygen was not needed, as reproducible standard curves could be obtained (Fig. 1b). 


\section{Comparison of current production to initial acetate concentration}

In order to test the reliability of the sensor signals, the peak current ( $5 \Omega$ external resistance) values (maximum current minus background current) obtained from acetate spiking were compared against the acetate concentration (Fig. 2).

The relationship between current peak values and acetate concentrations was linear (Fig. 2). Higher current peaks were obtained with higher concentrations of acetate. The presence of dissolved oxygen completely suppressed current production when the HCF(III) was absent (Fig. 2a). With increasing concentrations of HCF(III) current production was enhanced, resulting in higher sensitivities (current change per micromole of acetate added) and lower detection limits of the MFC biosensor (Table 1, Fig. 2). The detection limit was found to be $5 \mu \mathrm{M}$ (acetate), equivalent to $0.32 \mathrm{mg} / \mathrm{L}$ BOD. The minimum concentration was established by using a signal-to-noise ratio of between 3 or $2: 1$, which is generally considered acceptable for estimating the detection limit (FDA, 1996).

\section{Total coulombic charges and coulombic efficiency}

It has been demonstrated that same amount of acetate addition leads to a reproducible amount of total coulombic charges generated by anodophilic bacteria (Cheng et al., 2008). In order to calculate the total amount of coulombs produced here, the current was integrated from the beginning to the end of the peak. The coulometric signals were linearly related to acetate concentration (Fig. 3a). Similar to the amperometric measurement, the sensitivity and detection limit improved when the $\mathrm{HCF}$ (III) was added (Fig. 3a).

The coulombic efficiency represents the ratio of total coulombs transferred to the anode 
to the stoichiometrically expected coulombs (electron equivalents) for complete substrate oxidation. For a MFC biosensor operating in the presence of oxygen a high coulombic efficiency is desirable to obtain strong electrical signals.

In the current study, the coulombic efficiency was relatively constant for different acetate concentrations, which is in line with previous findings (Cheng et al., 2008), but depended strongly on the added HCF(III) concentration and DO level (Fig. 3b and 3c). In the absence of $\mathrm{HCF}$ (III) coulombic efficiencies were very low with $<1 \%$ in the presence and $<10 \%$ in the absence of oxygen. The generally low coulombic efficiencies $(<10 \%$ in the absence of oxygen) in MFC based biosensors were also observed in previous reports (Di Lorenzo et al., 2009), and were attributed to low levels of electromotively active oxidation-reduction products (Schröder, 2007).

The HCF(III) addition could significantly enhance the coulombic efficiency (Fig. 3a and 3b). For example, in the presence of a high concentration of $\mathrm{HCF}(\mathrm{III})(>0.8 \mathrm{mM})$, a dramatic increase in coulombic efficiency from 0 to about $40 \%$ (with oxygen present) was observed (Fig. 3c).

Compared to the peak current, which depends on the rate of microbial oxidation of AOC (Tront et al., 2008), the advantage of using total coulombic charges as a measurement parameter is that it is stoichiometrically related to the amount of organic carbon oxidized and hence a true indicator of the reducing power or feed value (e.g. calorific fuel value) of AOC present. Hence it would be expected to also give a meaningful response from a mixture of AOC compounds of different degradability, as they are present in ocean water. By contrast the determination of current peak could give low readings for more slowly degradable compounds (e.g. polymerized molecules 
such as peptides or polysaccharides).

\section{Responses to other organic substances}

For the purpose of scientific reproducibility, the sensor described here had been accustomed to the degradation of acetate as the model AOC. Acetate is used as model organic species in the water industry (Wang et al., 2011) and for MFC (Cheng et al., 2008). The reason is that acetate is not readily fermented or converted to other metabolites while more complex organics (carbohydrates, fats, proteins) are ultimately broken down to acetate under anaerobic conditions (Chen et al., 2008).

Although the marine MFC biosensor had been acclimated to acetate only, the response to other organic compounds commonly found in polluted seawater (Bright and Fletcher, 1983; Kaiser and Benner, 2009; Ogawa and Tanoue, 2003) was tested using a batchfeeding mode (Fig. 4). No signal was produced from L-glutamic, L-Aspartic acid, LMethionine and $\beta$-Alanine (data not shown) and only a faint signal was obtained from L-Arginine (Fig. 4). This is not surprising since the anodophilic biofilm was acclimated to acetate. The response to L-Ascorbic acid and the sugars glucose and sucrose (Fig. 4) could be caused by chemical reduction or fermentation respectively. After adaptation periods, MFC biofilms have been shown to be able to metabolize a variety of compounds (Luo et al., 2009; Galvez et al., 2009; Rezaei et al., 2009; Ren et al., 2008; Kim et al., 2000). Such an adaptation to different substrates by a shift in microbial population would not be feasible with traditional MFC biosensors using single strain of bacteria. Single strains MFC can metabolize a narrow substrate spectrum and also have a limited long-term stability, as the immobilised pure strain would be increasingly overgrown by native marine species. 


\section{Electron flow to different electron acceptors}

The previous experiments show the anodic current production can benefit from the addition of $\mathrm{HCF}(\mathrm{III})$ mediator, which indicates a different preferential electron pathway to the $\mathrm{HCF}(\mathrm{III})$. In order to test the affinity of the anodicphilic biofilm to different electron acceptors, i.e. oxygen, $\mathrm{HCF}(\mathrm{III})$, and the direct transfer to the anode, the electron transfer rates to various types of electron acceptors were quantified. The electron transfer rate was calculated as the amount of electrons transferred per hour.

Figure 5 shows the oxygen uptake rate (OUR), current production and $\mathrm{HCF}$ (III) consumption of the MFC-biosensor. In the absence of $\mathrm{HCF}(\mathrm{III})$ and the presence of oxygen and saturated concentrations of acetate, the oxygen consumption rate was 11.5 $\mathrm{mg} / \mathrm{L} /$ hour, equivalent to $144 \mu \mathrm{mol} \mathrm{e}^{-} /$hour (100 $\mathrm{mL}$ of anodic compartment), which was 4-times faster than the rate of the electron transfer to the anode $(0.96 \mathrm{~mA}$ equivalent to $36 \mu \mathrm{mol} \mathrm{\textrm {e }}$ /hour).

The addition of about $1 \mathrm{mM} \mathrm{HCF}(\mathrm{III})$ into the anode compartment immediately caused $\mathrm{HCF}(\mathrm{III})$ reduction and stopped oxygen consumption. This find ing is surprising as most previous research suggested a 100-times higher concentration of HCF (III) was required to outcompete oxygen ((Liu et al., 2010; Pasco et al., 2000; Yoshida et al., 2000). The rate of electron flow to HFC(III) was about 5 times higher $\left(700 \mu \mathrm{mol} \mathrm{e}^{-} /\right.$hour $)$than to oxygen (Fig. 5a and 5b). The reason why the marine MFC biosensor described here had a high affinity for $\mathrm{HCF}(\mathrm{III})$ could lie in the fact that our culture was enriched in the presence of $\mathrm{HCF}(\mathrm{III})$ as electron acceptor. Attempts to isolate the enriched HCF reducing bacteria are underway and will be published separately. 
The oxygen consumption gradually resumed to the previous level when about $95 \%$ of HCF(III) was reduced to $\mathrm{HCF}(\mathrm{II})$, which showed that the inhibition of oxygen consumption by $\mathrm{HCF}(\mathrm{III})$ was not due to the cyanide effect on the terminal oxidase as proposed by other authors (Chang et al., 2005), but caused by HCF(III) outcompeting oxygen for electrons liberated by the acetate oxidizing biofilm.

After $>95 \%$ of $\mathrm{HCF}$ (III) was reduced, the current flow was resumed by changing the external resistor from $1 \mathrm{M} \Omega$ to $5 \Omega$. A four-times higher current production was obtained compared to that in the absence of $\mathrm{HCF}(\mathrm{III})$, suggesting that $\mathrm{HCF}$ (II) readily transferred electrons to the anode $(+200 \mathrm{mV}$ vs $\mathrm{Ag} / \mathrm{AgCl})$ (Fig. 5b). However, the electron flow (calculated from current) from $\mathrm{HCF}$ (II) to the anode was about 4-times slower $\left(155 \mu \mathrm{mol} \mathrm{e}^{-} /\right.$hour $)$than the electron flow from the acetate oxidizing biofilm to the HCF(III) $(1 \mathrm{mM})$. This suggested that the rate limiting step in the HCF mediated electron transfer from biofilm to the anode was the anodic oxidation of $\mathrm{HCF}$ (II) rather than biological reduction of $\mathrm{HCF}(\mathrm{III})$.

Those bacterial strains that were enriched under the peculiar conditions of providing acetate as electron donor and $\mathrm{HCF}(\mathrm{III})$ as electron acceptor seemed to display a clear preference to using $\mathrm{HCF}(\mathrm{III})$ over oxygen. Anaerobically respiring bacteria such as iron-reducing bacteria are known to generate ATP from using anodes and also from using mediators such as humic substances (Straub et al., 2001). Hence it can be assumed that also the reduction of the mediator $\mathrm{HCF}(\mathrm{III})$ leads to the production of ATP (HCF(III) respiration). To what extent such $\mathrm{HCF}(\mathrm{III})$ based respiration could be a more effective respiration than oxygen respiration could be elucidated by future studies 
testing whether the ATP yield per mol of NADH in $\mathrm{HCF}(\mathrm{III})$ respiration is as high as that of oxygen.

\section{Continuous flow mode}

As an alternative to the above described batch mode of operation, a continuous flow through mode may be more applicable for the implementation of the marine biosensor MFC in-line with the seawater desalination process. As coulombic measurements are only suitable for batch operation, the reliability of cell voltage or current measurements needed to be tested in continuous flow mode.

During continuous flow trials, the DO of feedwater always stayed above $6.5 \mathrm{mg} / \mathrm{L}$ and the $\mathrm{HCF}$ (III) concentration was kept at $0.4 \mathrm{mM}$. Stepwise increases in acetate concentration in the inflow lead to corresponding increases in current or cell voltage. Even though the reducing power of the supplied acetate only allows partial reduction of the $\mathrm{HCF}(\mathrm{III})$, reproducible responses were obtained. The cell voltage signal could be amplified by using larger external resistances, however it required longer response times (more than one hour) to reach the steady state (Fig. 6). Under open-circuit conditions the response time was longer than 5 hours (data not shown).

\section{Conclusions}

This current study showed hexacyanoferrate-adapted anodophilic biofilm enables the development of a MFC biosensor to detect trace levels of AOC in nondeoxygenated seawater. As the hexacyanoferrate $(\mathrm{HCF}(\mathrm{III}))$ was found to enable the development of an adapted biofilm that transferred electrons to $\mathrm{HCF}(\mathrm{III})$ rather than oxygen, the marine MFC biosensor developed has been demonstrated to work in the presence of oxygen. The sensitivity and the detection limit of the sensor system can 
certainly be improved by improving the HFC(III) concentration. The MFC biosensor containing HFC(III) adapted-anodophilic biofilm that developed on the graphite tissue anode has shown sufficient sensitivity for the purpose of online seawater quality monitoring. In the current study acetate was only used as a preliminary substrate to establish a proof of concept and evaluate the sensor performance under the wellcontrolled conditions. However the mixed microbial consortium used is expected to be dynamic and adapt to other, more complex organic substances. Application of the marine MFC biosensor in seawater desalination plants, which are prone to biofouling of RO membranes, would assist operators to make quick corrective actions prior to a membrane biofouling occurrence.

\section{Acknowledgement}

The authors acknowledge the financial support of the National Centre of Excellence in Desalination Australia, which is funded by the Australian Government through the National Urban Water and Desalination Plan.

\section{References}

Appleby CA, Morton RK.1959. Lactic dehydrogenase and cytochrome b2 of baker's yeast: Purification and crystallization. Biochem J 71:492-499.

Baker RW. 2004. Microbial fuel cell biosensor for in situ assessment of microbial activity J.M. Membrane Technology and Applications, 2nd ed. New York: John Wiley \& Sons.

Bond DR, Lovely DR. 2003. Electricity production by Geobacter sulfurreducens attached to electrodes. Appl Environ Microbiol 69:1548-1555.

Bonetto MC, Sacco NJ, Ohlsson AH, Cortón E. 2011. Assessing the effect of oxygen 
and microbial inhibitors to optimize ferricyanide-mediated BOD assay. Talanta 85:455462.

Bourgeois W, Burgess EJ, Stuetz RM. 2001. On-line monitoring of wastewater quality: a review. J Chem Technol Biotechnol 76:337-348.

Bright JJ, Fletcher M. 1983. Amino-acid assimilation and electron transport system activity in attached and free-living marine-bacteria. Appl Environ Microbiol 45:818825.

Brouwer H, Meesters K, van Groenestijn J. 2006. Biofouling control in reverse osmosis membranes using rapid biofiltration technology. Desalination 199:15-17.

Chang IS, Moon H, Jang JK, Kim BH. 2005. Improvement of a microbial fuel cell performance as BOD sensor using respiratory inhibitors. Biosens Bioelectron 20:18561859.

Chee GJ, Nomura Y, Karube I. 1999. Biosensor for the estimation of low biochemical oxygen demand. Anal Chim Acta 379:185-191.

Chen H, Ye T, Qiu B, Chen G, Chen X. 2008. A novel approach based on ferricyanidemediator immobilized in an ion-exchangeable biosensing film for the determination of biochemical oxygen demand. Anal Chim Acta 612:75-82.

Chen Y, Cheng JJ, Creamer KS. 2008. Inhibition of anaerobic digestion process: A review. Bioresour Technol 99:4044-4064.

Cheng KY, Goen H, Cord-Ruwisch R. 2008. Affinity of microbial fuel cell biofilm for the anodic potential. Environ Sci Technol 42:3828-3834.

Di Lorenzo M, Curtis TP, Head IM, Scott K. 2009. A single-chamber microbial fuel cell as a biosensor for wastewaters. Water Res 43:3145-3154.

Eaton D, Franson MAH. 2005. Standard Methods for the Examination of Water and 
Wastewater. American Public Health Association.

FDA, 1996. U.S. Department of Health and Human Services, Food and Drug Administration, Center for Drug Evaluation and Research (CDER), Center for Biologics Evaluation and Research (CBER). Guidance for Industry, Q2B Validation of Analytical Procedures: Methodology, p. 7.

Galvez A, Greeman J, Ieropoulos I. 2009. Landfill leachate treatment with microbial fuel cells: scale-up through plurality. Bioresour Technol 100:5085-5091.

Hobbie, JE, Daley RJ, Jasper S. 1977. Use of nucleopore filters for counting bacteria by fluorescence microscopy. Appl Environ Microbiol 33:1225-1228.

Holm-Hansen O, Booth CR. 1996. Measurement of adenosine triphosphate in the ocean and its ecological significance. Limnol Oceanogr 11:510-519.

Jordan MA, Welsh DT, John R, Catterall K, Teasdale PR. 2013. A sensitive ferricyanide-mediated biochemical oxygen demand assay for analysis of wastewater treatment plant influents and treated effluents. Water Res 47:841-849.

Jordan MA, Welsh DT, Teasdale PR, Catterall K, John R. 2010. A ferricyanidemediated activated sludge bioassay for fast determination of the biochemical oxygen demand of wastewaters. Water Res 44:5981-5988.

Kaiser K, Benner R. 2009. Biochemical composition and size distribution of organic matter at the Pacific and Atlantic time-series stations. Marine Chemistry 113:63-77.

Kim N, Choi Y, Jung S, Kim S. 2000. Effect of initial carbon sources on the performance of microbial fuel cells containing Proteus vulgaris. Biotechnol Bioeng 70:109-114.

Kumlanghan A, Liu J, Thavarungkul P, Kanatharana P, Mattiasson B. 2007. Microbial fuel cell-based biosensor for fast analysis of biodegradable organic matter. Biosens 
Bioelectron 22:2939-2944.

Ling M, Rifai HS, Newell CJ, Aziz JJ, Gonzales JR. 2003. J Environ Monit 5:126-134.

Liu H, Cheng S, Logan BE, 2005. Eviron. Power generation in fed-batch microbial fuel cells as a function of ionic strength, temperature, and reactor configuration. Environ Sci Technol 39:5488-5493.

Liu J, Björnsson L, Mattiasson B. 2000. Immobilised activated sludge based biosensor for biochemical oxygen demand measurement. Biosens Bioelectron 14:883-893.

Liu L, Shang L, Liu C, Liu C, Zhang B, Dong S. 2010. A new mediator method for BOD measurement under non-deaerated condition. Talanta 81:1170-1175.

Liu Z, Liu J, Zhang S, Xing X, Su Z. 2011. Microbial fuel cell based biosensor for in situ monitoring of anaerobic digestion process. Bioresour Technol 102:10221-10229. Logan BE, Hamelers B, Rozendal R, Schröder U, Keller J, Freguia S, Aelterman P, Verstraete W, Rabaey K. 2006. Microbial fuel cells: methodology and technology. Environ Sci Technol 40:5181-5192.

Luo H, Liu G, Zhang R, Jin S. 2009. Phenol degradation in microbial fuel cells. Chem Eng J 147:259-264.

Matin A, Khan Z, Zaidi SMJ, Boyce MC. 2011. Biofouling in reverse osmosis membranes for seawater desalination: Phenomena and prevention. Desalination 281:116.

Modin O, Wilén BM. 2012. A novel bioelectrochemical BOD sensor operating with voltage input. Water Res 46:6113-6120.

Nakamura H, Suzuki K, Ishikuro H, Kinoshita S, Koizumi R, Okuma S, Gotoh M, Karube I. 2007. A new BOD estimation method employing a double-mediator system by ferricyanide and menadione using the eukaryote Saccharomyces cerevisiae. Talanta 
$72: 210-216$.

Nguyen T, Roddick AF, Fan L. 2012. Biofouling of water treatment membranes: a review of the underlying causes, monitoring techniques and control measures. Membr 2:804-840.

Ogawa H, Tanoue E. 2003. Dissolved Organic Matter in Oceanic Waters. J Oceanogr 59:127-147.

Pasco N, Baronian K, Jeffries C, Hay J. 2000. Biochemical mediator demand-a novel rapid alternative for measuring biochemical oxygen demand. Appl Microbiol Biotechnol 53:613-618.

Pant D, Bogaert GV, Diels L, Vanbroekhoven K. 2010. A review of the substrates used in microbial fuel cells (MFCs) for sustainable energy production. Bioresour Technol 101:1533-1543.

Pasco N, Baronian K, Jeffries C, Webber J, Hay J. 2004. MICREDOX(R)-development of a ferricyanide-mediated rapid biochemical oxygen demand method using an immobilised Proteus vulgaris biocomponent. Biosens Bioelectron 20:524-532.

Ren Z, Steinberg LM, Regan JM. 2008. Electricity production and microbial biofilm characterization in cellulose-fed microbial fuel cells. Water Sci Technol 58:617-622.

Rezaei F, Richard TL, Logan BE. 2008. Analysis of chitin particle size on maximum power generation, power longetivity, and coulombic efficiency in solid-substrate microbial fuel cells. J Power Sourc 192:304-30-9.

Ringeisen BR, Ray R, Little B. 2007. A miniature microbial fuel cell operating with an aerobic anode chamber. J Power Sourc 165:591-597.

Saad MA. 2004. Early discovery of RO membrane fouling and real-time monitoring of plant performance for optimizing cost of water. Desalination 165:183-191. 
Sangeetha S, Sugandhi G, Murugesan M, Madhav V, Berchmans S, Rajasekar R, Rajasekar S, Jeyakumar D, Rao GP. Electroanalysis, 1996, Torulopsis candida based sensor for the estimation of biochemical oxygen demand and its evaluation. Electroanalysis, 8:698-701.

Schröder U. 2007. Anodic electron transfer mechanisms in microbial fuel cells and their energy efficiency. Phys Chem Chem Phys 9:2619-2629.

Shukla AK, Suresh P, Berchmans S, Rajendran A. 2004. Biological fuel cells and their applications. Curr Sci 87:455-468.

Straub KL, Benz M, Schink B. 2001. Iron metabolism in anoxic environments at near neutral pH. FEMS Microbiol Ecol 34:181-186.

Taki M, Suzuki Y. 2001. Accumulation and export of dissolved organic carbon in surface waters of subtropical and tropical pacific ocean. J Oceanogr 57:631-646.

Tront JD, Fortner JD, Plötze M, Hughes JB, Puzrin AM. 2008. Microbial fuel cell biosensor for in situ assessment of microbial activity. Biosens Bioelectron 24:586-590.

Riedel K, Lehmann M, Tag K, Renneberg R, Kunze G. 1998, Arxula adeninivorans Based Sensor for the Estimation of BOD. Anal Lett 31:1-12.

Van der Kooij D, Hijnen WAM, Cornelissen ER. 2010. Biofouling of spiral-wound Membranes in water treatment. Water Research Foundation: Denver, CO, USA.

Van der Kooij D. 1992. J Am Water Work Assoc 84, 57-65.

Wang YK, Sheng GP, Li WW, Huang YX, Yu YY, Zeng RJ, Yu HQ. 2011. Development of a novel bioelectrochemical membrane reactor for wastewater treatment. Environ Sci Technol 45:9256-9261.

Yoshida N, Yano K, Morita T, McNiven SJ, Nakamura H, Karube I. 2000. A mediatortype biosensor as a new approach to biochemical oxygen demand estimation. Analyst 
$125: 2280-2284$.

Figure 1. Responses to the addition of traces of acetate by the established marine MFC biosensor in the absence (a) and the presence of $\mathrm{HCF}$ (III) $(0.2 \mathrm{mM})$ after 2 weeks of adaptation (b). (Solid line: cell voltage (solid arrows: acetate addition); dash line: dissolved oxygen (solid arrows: start aeration, dash arrows: stop aeration))

Figure 2. Correlation of peak current with the acetate concentration added for different $\mathrm{HCF}(\mathrm{III})$ concentrations in the marine MFC biosensor. Concentrations of HCF(III) (mM) were 0.8 (squares), 0.4 (triangles) 0.2 (diamonds) and 0 (spheres). Dissolved oxygen was $>6$ (open symbols) and $0 \mathrm{mg} / \mathrm{L}$ (closed symbols). Results show averages of triplicate measurements.

Figure 3. Effect of added HCF(III) concentrations on (a) total produced coulombic, charges coulombic efficiencies of the marine MFC biosensor in the absence (b) and presence (c) of dissolved oxygen. Results are the averages of triplicates. Concentrations of $\mathrm{HCF}(\mathrm{III})(\mathrm{mM})$ were 0.8 (squares), 0.4 (triangles) 0.2 (diamonds) and 0 (spheres). Dissolved oxygen was $>6$ (open symbols) and $0 \mathrm{mg} / \mathrm{L}$ (closed symbols).

Figure 4. Response of acetate adapted marine MFC biosensor to more complex organic substances $(\mathrm{DO}>6 \mathrm{mg} / \mathrm{L}, \mathrm{HCF}(\mathrm{III})=0.4 \mathrm{mM}$, external resistance $=5 \mathrm{ohm})$

Figure 5. Effect of $\mathrm{HCF}(\mathrm{III})$ addition to the acetate saturated marine MFC biosensor on biofilm oxygen uptake and current production. (a) Profiles of DO (triangle), current (square) and $\mathrm{HCF}(\mathrm{III})$ concentration (circle). Arrows indicate: (1) $5 \mathrm{ohm}$ and aeration, (2) $1 \mathrm{Mohm}$, (3) aeration stopped, (4) addition of $1 \mathrm{mM} \mathrm{HCF(III),} \mathrm{(5)} 5 \mathrm{ohm}$ and aeration. (b) Electron transfer rates to $\mathrm{HCF}$ (III) (circle), oxygen (triangle) and anode (square). 
Figure 6. Cell voltage (thick line) and current (thin line) responses of the marine MFC biosensor to step changes in acetate concentration of the inflow under continuous flow mode. Small resistors $(5 \mathrm{ohm})$ and large resistors $(1000 \mathrm{ohm})$ amplify the current and cell voltage signals respectively. 
Figure 1
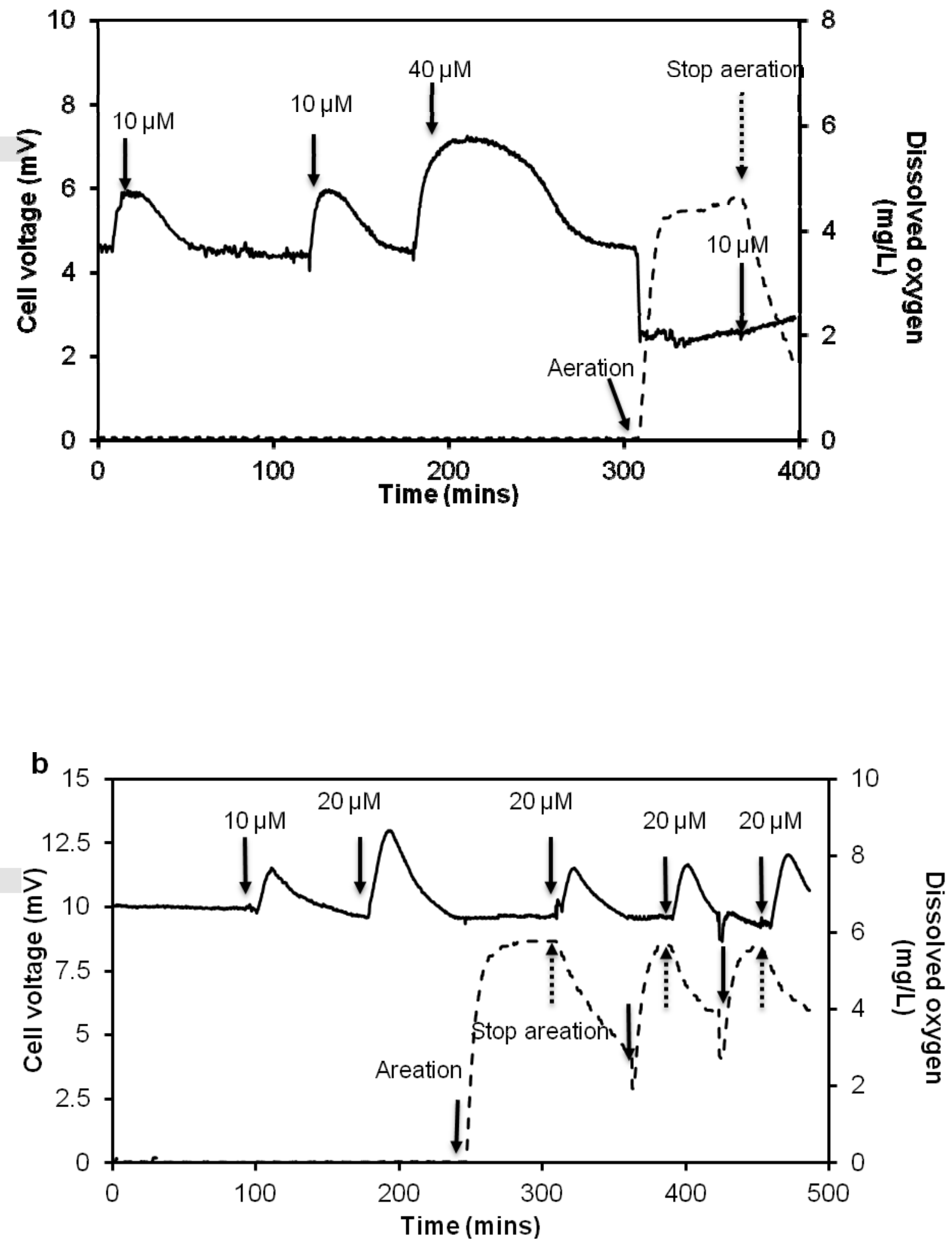
Figure 2

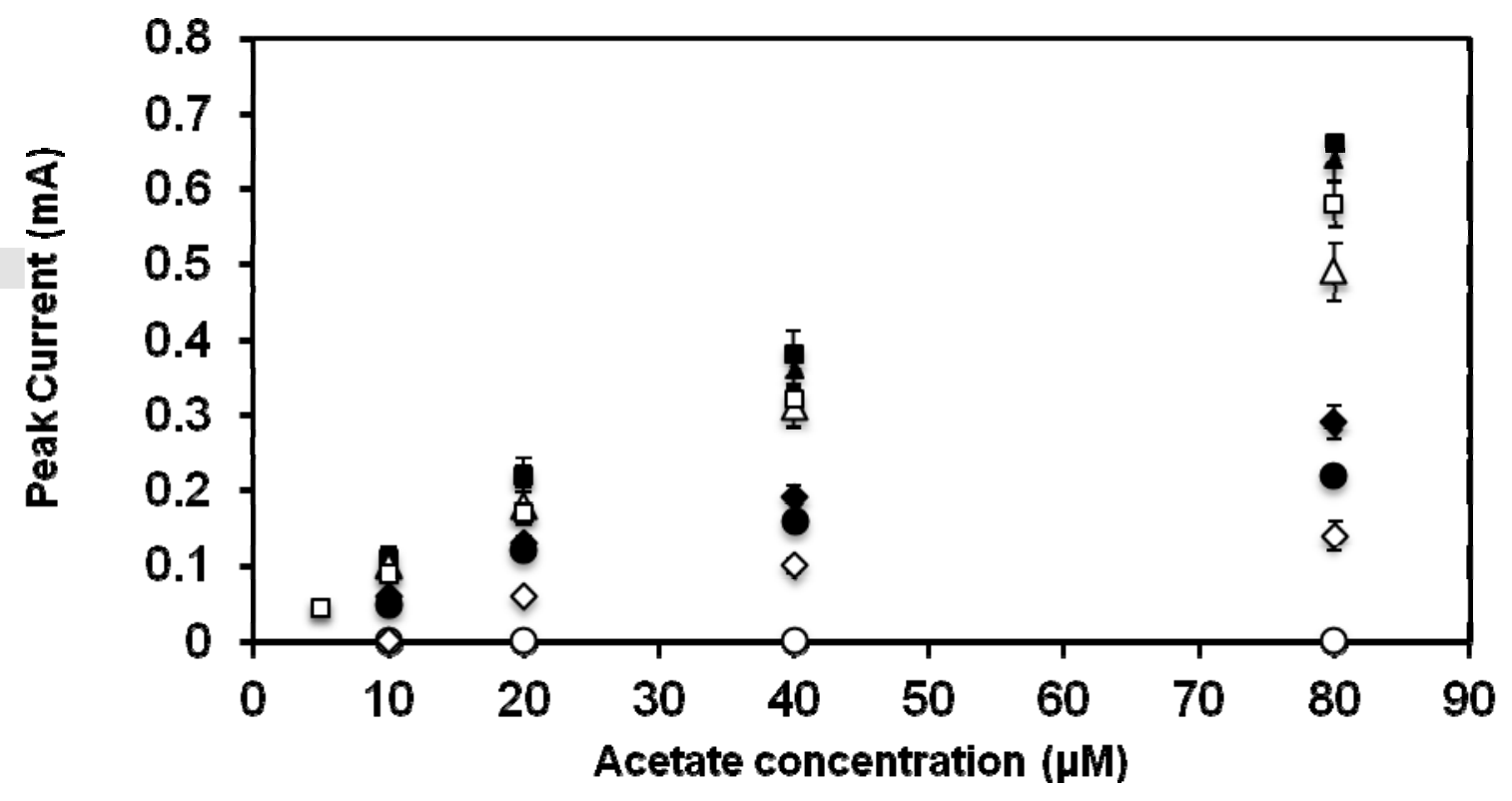


Figure 3
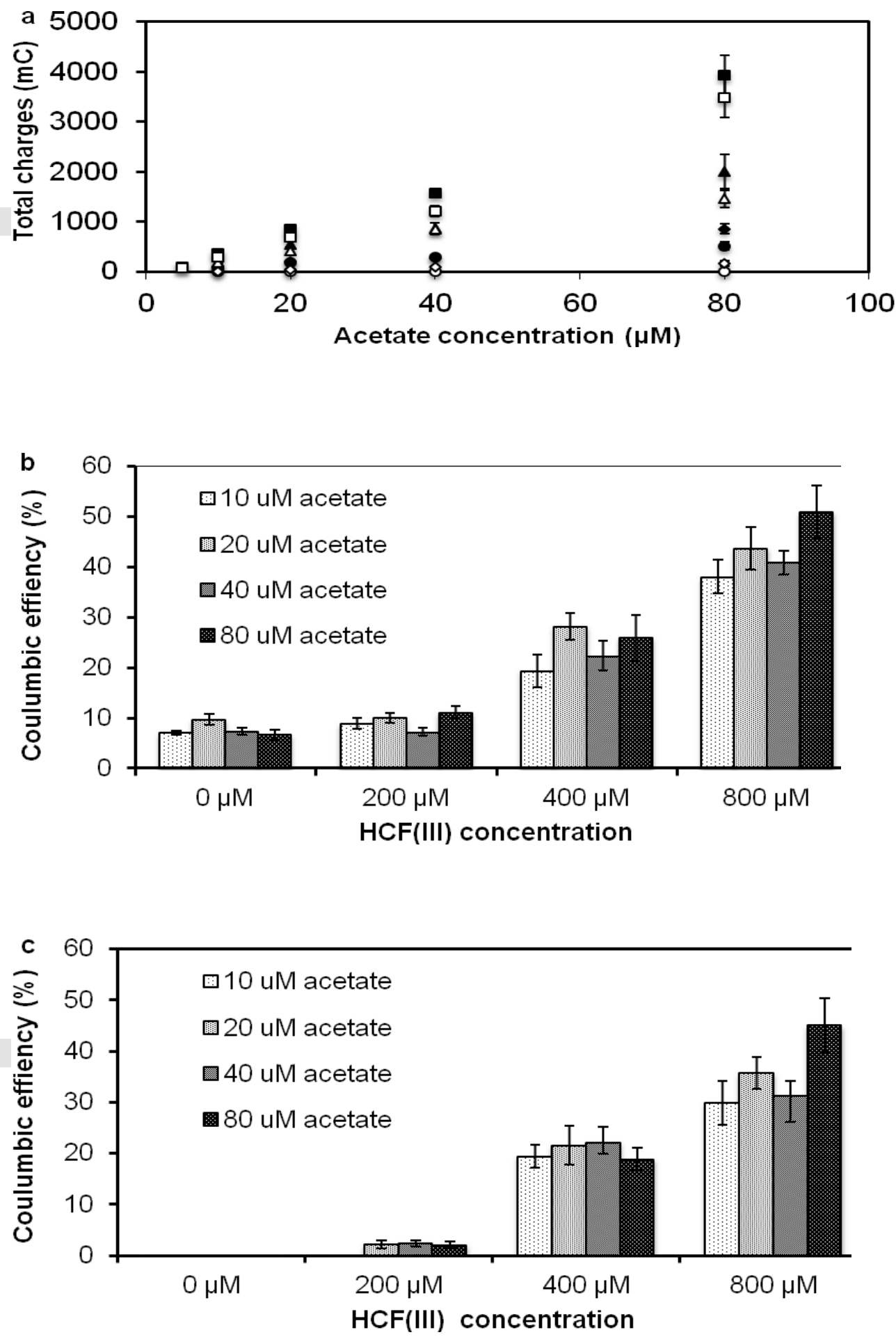
Figure 4
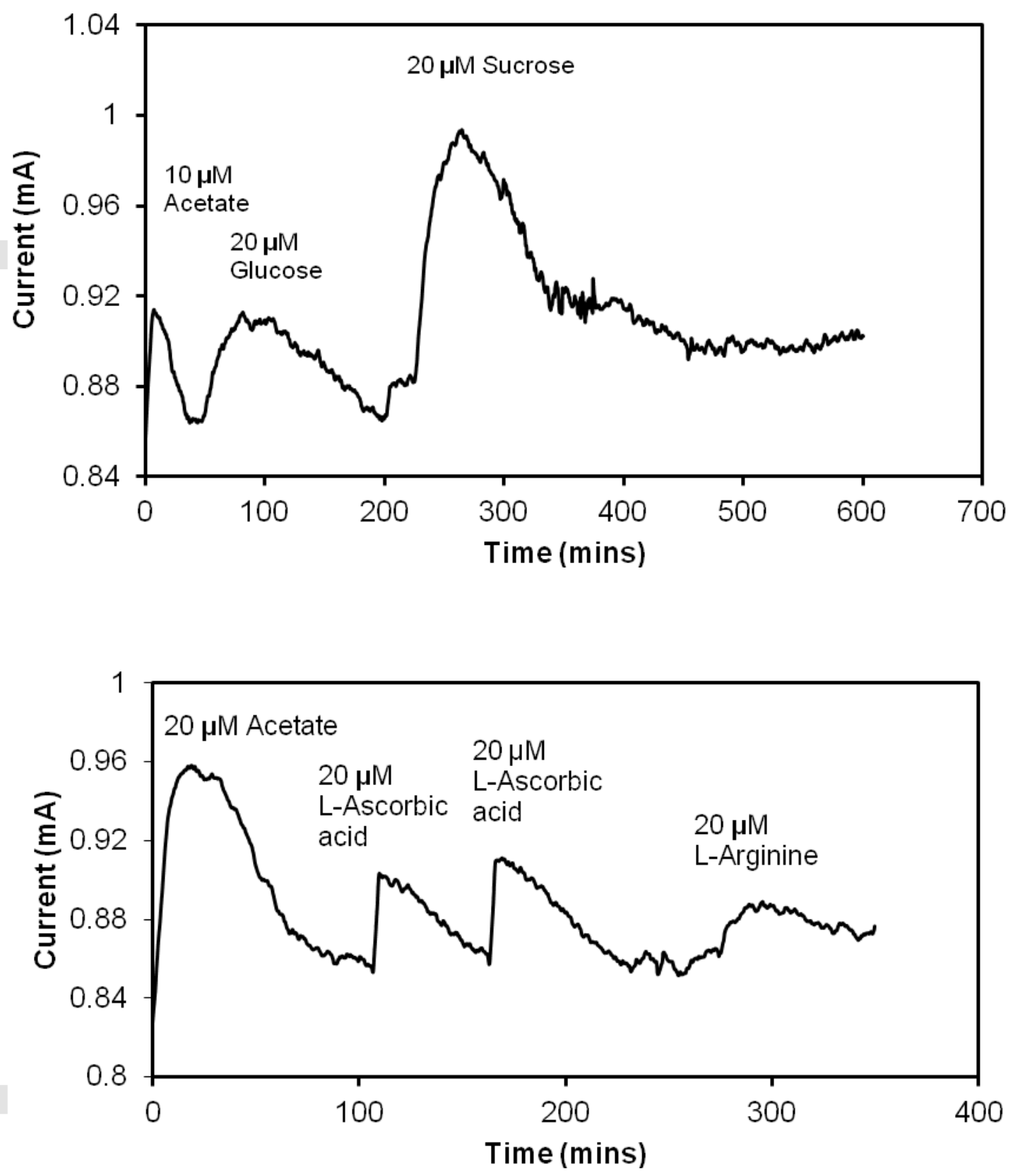
Figure 5
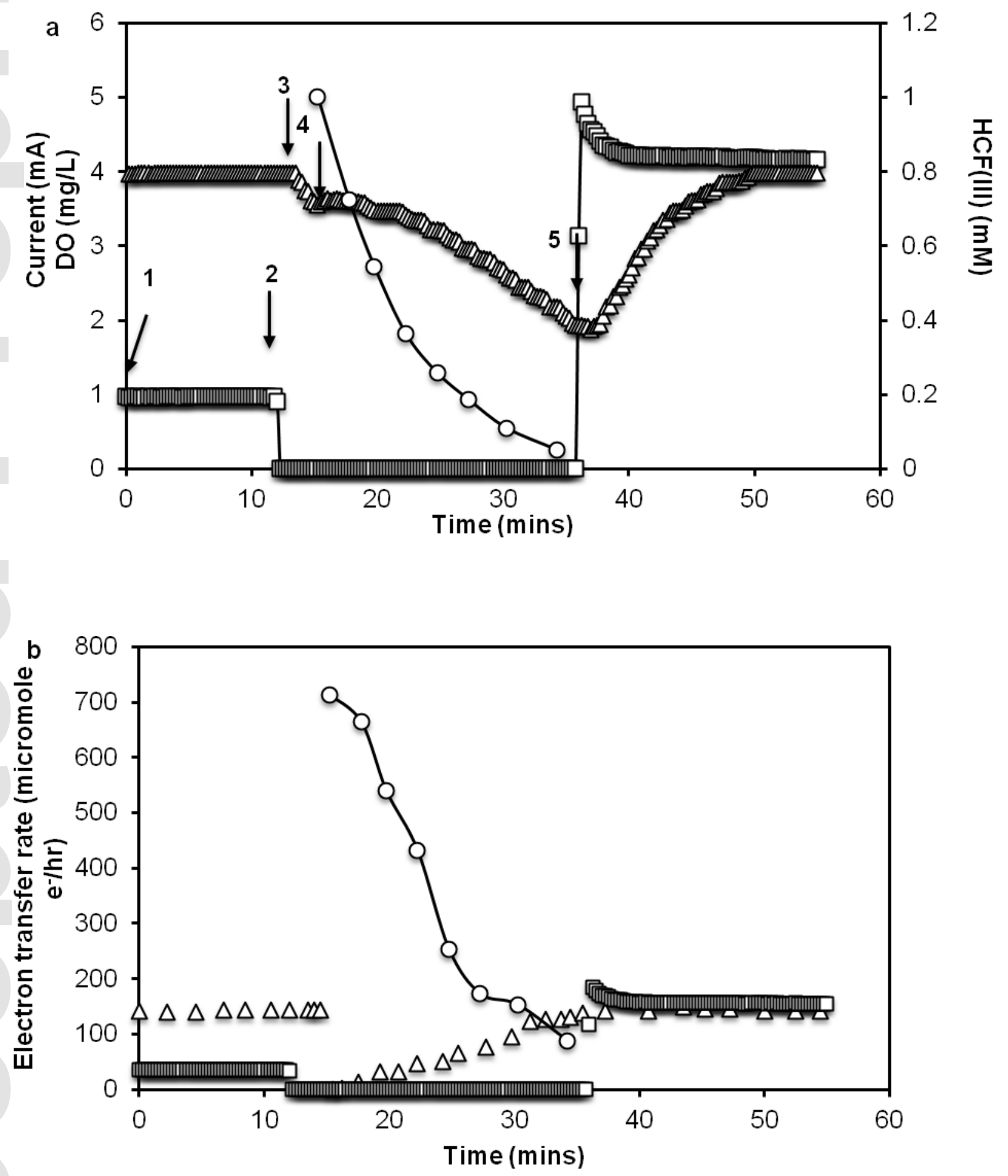
Figure 6

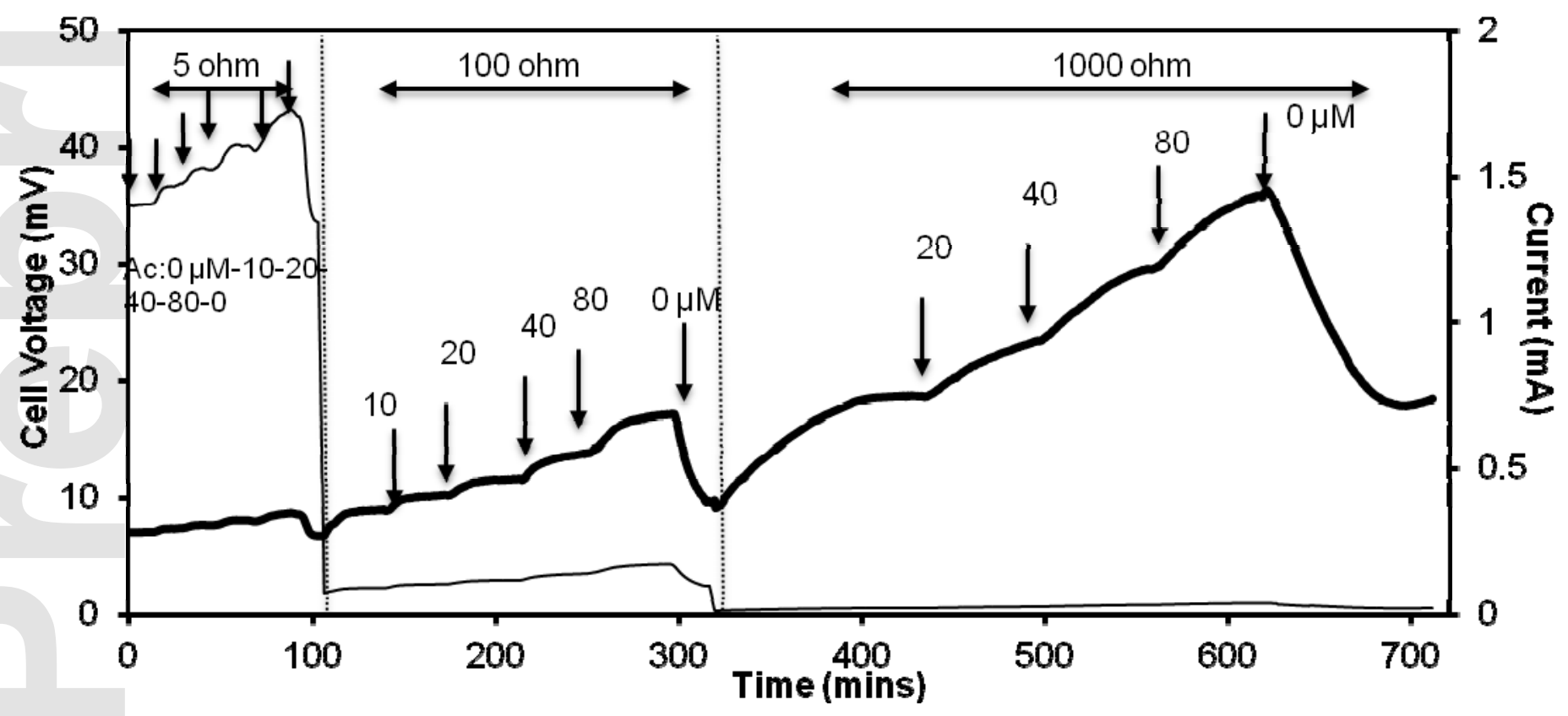


Table 1. Effect of HCF(III) on the correlation between acetate concentration and current peak production under anaerobic and aerobic anodic conditions $(n=3)$.

\begin{tabular}{|c|c|c|c|c|c|}
\hline $\begin{array}{l}\text { HCF(III) } \\
\text { concentration } \\
(\mathrm{mM})\end{array}$ & $\begin{array}{l}\text { Dissolved } \\
\text { oxygen } \\
(\mathrm{mg} / \mathrm{L})\end{array}$ & $\begin{array}{l}\text { Sensitivity } \\
(\mu \mathrm{A} / \mu \mathrm{M} \\
\text { acetate })\end{array}$ & $\begin{array}{l}\text { Detection } \\
\text { limit ( } \mu M \\
\text { acetate) }\end{array}$ & Linearity Equation & $\mathbf{R}^{2}$ \\
\hline 0 & 0 & 2.2 & 10 & $Y=0.0022 x+0.0557$ & 0.897 \\
\hline 0 & $>6$ & n.d. & n.d. & $\mathrm{n} / \mathrm{a}$ & $\mathrm{n} / \mathrm{a}$ \\
\hline 0.2 & 0 & 3.1 & 10 & $Y=0.0031 x+0.0517$ & 0.962 \\
\hline 0.2 & $>6$ & 1.8 & 20 & $Y=0.0018 x+0.0078$ & 0.862 \\
\hline 0.4 & 0 & 7.5 & 5 & $Y=0.0075 x+0.0496$ & 0.992 \\
\hline 0.4 & $>6$ & 5.5 & 5 & $Y=0.0055 x+0.0652$ & 0.985 \\
\hline 0.8 & 0 & 8.0 & 5 & $Y=0.008 x+0.0342$ & 0.990 \\
\hline 0.8 & $>6$ & 7.1 & 5 & $Y=0.0071 x+0.0213$ & 0.997 \\
\hline
\end{tabular}

n.d.= not detectable; $\mathrm{n} / \mathrm{a}=$ not applicable. 